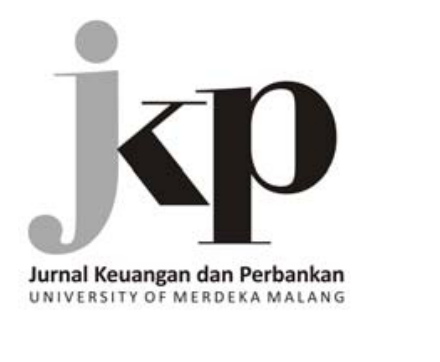

Article history:

Received: 2017-11-23

Revised: 2017-12-22

Accepted: 2018-02-15

\section{Riko Hendrawan}

Program of Magister

Management, Telkom University

Jl. Gegerkalong Hilir No.47,

Bandung, 40152

\section{Riko Hendrawan (Indonesia)}

\section{Assessing Shock Volatility using Long Straddle Option Strategy: Evidence at IDX Composite}

\begin{abstract}
This study is to identify the probability of occurrence of shock volatility and its impact on return of an investment. Using IDX Composite data from 1998-2016 and long straddle option strategy at IDX composite consisting of 2 phases, high volatility daily return are 7 years with a total of 3432 observations, using 1716 call option simulation contracts, and 1716 put option simulation contracts and low volatility daily return are 12 years with a total of 5528 observations, using 2908 call option simulation contracts and 2908 put option simulation contracts. The result shows that the shock volatility occurs greater when the volatility below the average year of observation. Shock volatility during the year low volatility of 44.25 percent and period of year high volatility of 34.49 percent. But if calculated in total, based on 8960 observation from 1998-2016, where 4480 is call option and 4480 transaction is put transaction there is 1815 incident shock volatility or equal to 40.51 . So the potential for profit (call and put option holders) or potential loss (call and put option seller) per day due to the occurrence of shock volatility of 40.51 percent.
\end{abstract}

Keywords: Call Option; Option Straddle Strategy; Put Option; Shock Volatility JEL Classification: G13; G17

Citation: Hendrawan, R. (2018). Assessing shock volatility using long straddle option strategy: Evidence at IDX Composite. Jurnal Keuangan dan Perbankan, 22(1): 1-13. https:// doi.org/10.26905/jkdp.v22i1.1707

\begin{abstract}
Abstrak
Tujuan penelitian ini adalah mengidentifikasi terjadinya volatilitas kejutan dan implikasinya terhadap imbal hasil suatu investasi. Menggunakan data IHSG dari tahun 1998-2016 menggunakan strategi opsi straddle terbagi atas 2 fase yaitu IHSG memiliki volatilitas yang tinggi sebanyak 7 tahun dengan 13432 observasi dengan opsi beli dan jual masing-masing sebanyak 1716 kontrak simulasi dan IHSG memiliki volatilitas yang rendah sebanyak 12 tahun dengan 5528 observasi dengan opsi beli dan jual masing-masing sebanyak 2764 kontak simulasi. Hasil penelitian menunjukkan bahwa selama tahun volatilitas rendah shock volatilitas terjadi sebanyak $44,25 \%$, sedangkan tahun volatilitas tinggi terjadi sebanyak $34,49 \%$. Jadi secara keseluruhan dari tahun 1998-2016 dengan total observasi 8960, dimana 4480 opsi beli dan 4480 opsi jual terjadi sebanyak 1815 volatilitas kejutan atau sekitar 40,51\% dari total observasi. Sehingga potensi terjadinya keuntungan (bagi pemegang opsi beli ataupun opsi jual) ataupun potensi kerugian (bagi penjual opsi beli ataupun opsi jual) per hari akibat terjadinya volatilitas kejutan sebesar $40.51 \%$.
\end{abstract}

Kata Kunci: Opsi Beli; Opsi Strategi Straddle; Opsi Jual; Volatilitas Kejutan
Riko Hendrawan: Tel +62 22201 1388; Fax +62 2220113887

Email: riko_hendrawan@yahoo.com
ISSN: 2443-2687 (Online) ISSN: 1410-8089 (Print) 
During the last 20 years from 1998-2016, there were 2 crises that hit the Indonesian economy. The first is Asian economic crisis in 1998, The crisis resulted from a collapse of confidence in the ability of a number of Southeast Asian countries to maintain their fixed exchange rates while continuing to allow the free movement of foreign finance capital at a time of increasing current account deficits. The second one is subprime mortgage crisis in 2008, the crisis can be attributed to a number of factors pervasive in both housing and credit markets, factors which emerged over a number of years.

The impact of the 1998 economic crisis on the composite stock price index (IDX Composite) is very large. Which in early 1998 IDX Composite was at 410 level points, at the height of the crisis 1998 IDX Composite fell sharply on October $6^{\text {th }}, 1998$ to the level of 258 points or corrected by minus 37.07 percent. In the 2008 crisis, the IDX Composite opened at 2731 points while at the peak of the 2008 crisis IDX Composite fell sharply on October $28^{\text {th }}, 2008$ to the level of 1111 points or corrected by minus 59.31 percent. Furthermore, based on daily return of IDX Composite from January 1998 to December 1998 on Figure 1, shows that the strengthening and weakening of IDX Composite during 1998 ranged from 9.29 percent to 14.03 percent per day.

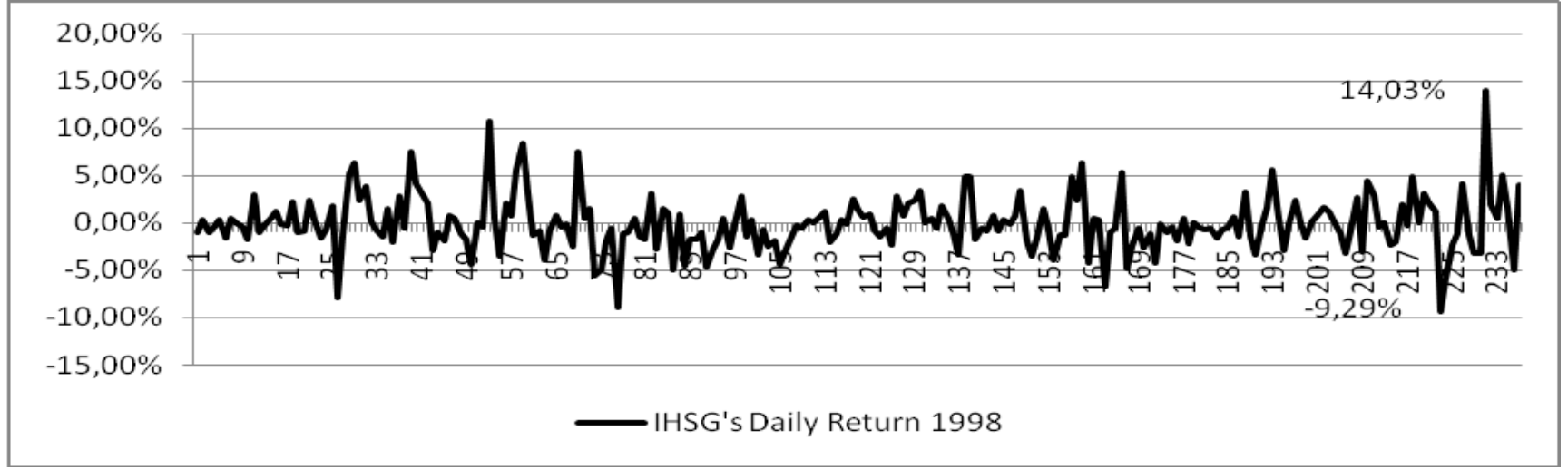

Processed by author

Figure 1. Daily Return of IDX Composite in 1998

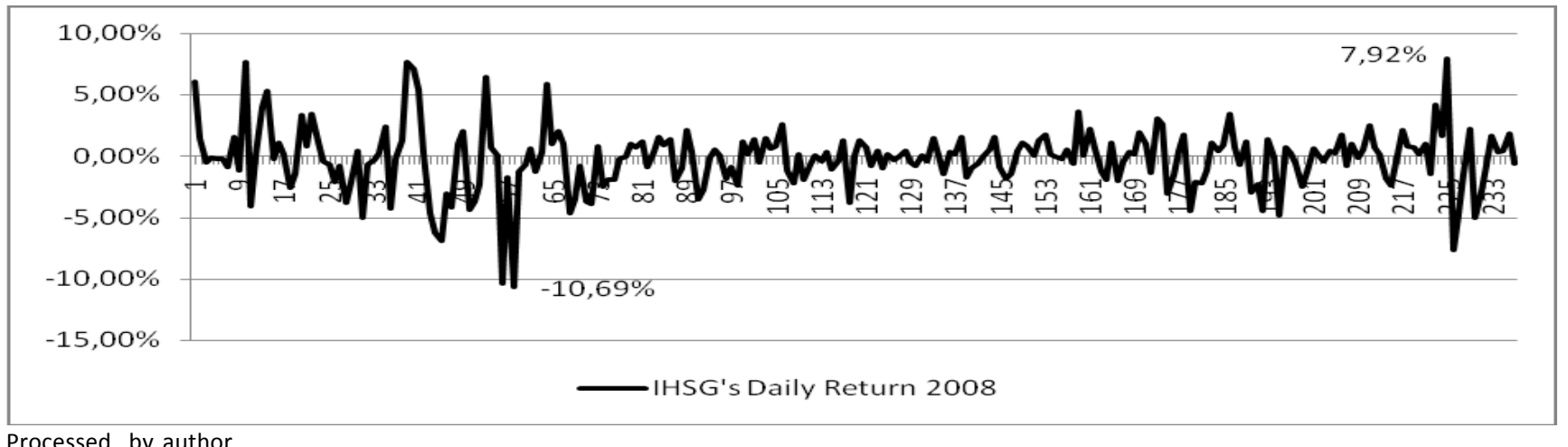

Figure 2. Daily Return of IDX Composite in 2008 
While based on daily return data of IDX Composite January 2008 to December 2008 on Figure 2 shows that the strengthening and weakening of IDX Composite during the year 2008 ranged from -10.69 percent to 7.92 percent per day.

If investigated further over the last 20 years based on Table 1 during the period of 1998-2016, the lowest daily return of IDX Composite occurred on September $26^{\text {th }}, 2006$ of -10.69 percent and the highest occurred on February $11^{\text {th }}, 1998$. The lowest daily average return for 20 years at -5.72 percent and the highest daily average return of 5.75 percent. On the other hand, the range of daily return for 20 years ranged from 6.86 percent to 23.32 percent with an average daily return range of 11.48 percent.

From the range of daily return the average percentage of deviation at the lowest of -44.33 percent occurred in 2014 and the highest of 103.22 percent occurred in 1998. The percentage of deviation below 0 percent indicates the low volatility of daily yields on average over the past 20 years, while the percentage deviation above 0 percent indicates the high volatility of daily returns on average over the last 20 years. The daily return of the IDX Composite sequentially from 1998-2016 with average daily returns higher than 0 percent occurred in 1998, 1999, 2004, 2006, 2007, 2008, and 2011 respectively.

The data in Table 1 shows that the volatility during 1998-2016 varies greatly so it needs to be observed by the researchers to evaluate the probability of occurrence of shock volatility of an investment instrument. The impact of the occurrence of shock volatility will result in rising or falling prices of an investment instrument above or below the historical volatility. Çýnar \& Uzmay (2017) investigated impact the volatility to food price, they stated that variance shocks in the fear index damage food prices. The results may be useful to policy makers in researching the causes of changes in the prices of food commodity and taking necessary measures. Hendrawan (2017) investigated impact the volatil-

Table 1. Daily Return of IDX Composite 1998-2016

\begin{tabular}{|c|c|c|c|c|c|}
\hline \multicolumn{2}{|c|}{ Low Daily Retun } & \multicolumn{2}{|c|}{ High Daily Return } & \multirow{2}{*}{ Range \% } & \multirow{2}{*}{$\begin{array}{c}\text { Percentage } \\
\text { of Deviation \% }\end{array}$} \\
\hline Date & Percentage $\%$ & Date & Percentage $\%$ & & \\
\hline Oct 10, 2016 & -4.01 & Feb 04, 2016 & 2.85 & 6.86 & -40.23 \\
\hline Aug 21, 2015 & -3.97 & Aug 26, 2015 & 4.55 & 8.52 & -25.73 \\
\hline Apr 09, 2014 & -3.16 & Mar 13, 2014 & 3.23 & 6.39 & -44.33 \\
\hline Aug 16, 2013 & -5.58 & Sep 18, 2013 & 4.65 & 10.23 & -10.84 \\
\hline Jun 01, 2012 & -3.82 & Jun 05, 2012 & 3.32 & 7.14 & -37.77 \\
\hline Sep 21, 2011 & -8.88 & Sep 26, 2011 & 4.76 & 13.64 & 18.84 \\
\hline May 04, 2010 & -3.81 & May 25, 2010 & 7.27 & 11.08 & -3.49 \\
\hline Jun 17, 2009 & -3.65 & Apr 08, 2009 & 5.09 & 8.75 & -23.79 \\
\hline Sep 26, 2008 & -10.69 & Jan 22, 2008 & 7.92 & 18.61 & 62.17 \\
\hline Aug 14, 2007 & -6.44 & Aug 16, 2007 & 6.97 & 13.40 & 16.76 \\
\hline May 12, 2006 & -6.31 & Jun 15, 2006 & 5.47 & 11.77 & 2.60 \\
\hline Aug 26, 2005 & -5.16 & Aug 29, 2005 & 4.53 & 9.69 & -15.60 \\
\hline May 14, 2004 & -7.50 & May 18, 2004 & 4.53 & 12.04 & 4.88 \\
\hline Aug 04, 2003 & -3.06 & Apr 04, 2003 & 4.47 & 7.53 & -34.41 \\
\hline Oct 11, 2002 & -5.36 & Oct 15, 2002 & 4.44 & 9.79 & -14.67 \\
\hline Jul 23, 2001 & -5.75 & Feb 01, 2001 & 4.97 & 10.72 & -6.59 \\
\hline Sep 13, 2000 & -7.03 & Jun 07, 2000 & 4.08 & 11.11 & -3.22 \\
\hline Jul 23, 1999 & -5.29 & Jun 07, 1999 & 12.18 & 17.47 & 52.20 \\
\hline Feb 11, 1998 & -9.29 & Jan 28, 1998 & 14.03 & 23.32 & 103.22 \\
\hline Average & -5.72 & Average & 5.75 & 11.48 & 0.00 \\
\hline
\end{tabular}


ity in managing currency risk. He found that the forward contract can be used as a hedging tool of the uncertainty of the movement of an investment instrument. Sudha (2015) investigated the impact of volatility through the performance of index in India. The results indicate that though the daily compounded returns to the ESG India Index are not statistically different from those of the Nifty or those of the CNX 500. Annualised returns of the ESG India Index have been better than the returns of the other 2 indexes and there is significant volatility clustering in all the 3 indexes. Tripathy (2011) finds the evidence of leverage and asymmetric effect of macroeconomic variables in stock market and indicates that bad news generate more impact on the volatility of the stock price in the market. Further the study concludes that asymmetric GARCH models provide better prediction result than the symmetric $\mathrm{GARCH}$ model.

From the above researchers focus on the volatility model and the movement of selected investment instruments whether to rise or fall the instrument. In the investment world, there is an investment instrument called option which gives the investor the choice of investment if the investment instrument goes up by buying call option or if its investment instrument dropped by buying a put option. So investors ignore the rise or fall of underlying assets but rather focus on whether the volatility of the underlying assets has high or low volatility. One of the options strategy is straddle position. The long straddle position strategy indicates that the buyer calls and puts simultaneously at the same exercise price and time period. This means the buyer believes that there will be greater volatility of historical volatility in the investment instrument regardless of the rise or fall of the investment instrument.

Based on phenomenon and previous research. this study has a goal to identify the probability of occurrence of shock volatility and its impact on return of an investment. Using index data from 1998-
2016 using long straddle option strategy at IDX Composite consisting of 2 phases: (1) high volatility daily return of IDX Composite in 1998, 1999, 2004, 2006, 2007, 2008, and 2011; and (2) low volatility daily return of IDX Composite in 2000, 2001, 2002, 2003, 2005, 2009, 2010, 2012, 2013, 2014, 2015.

\section{Black-Scholes Option Pricing Theory}

According to Bodie, Kane, \& Marcus (2014), the Black Scholes pricing formula for a call option is:

$c=S_{0} N\left(d_{1}\right)-X e^{-r T} N\left(d_{2}\right)$

And for the put option is:

$\mathrm{p}=\mathrm{Xe} \mathrm{erT}^{-\mathrm{T}} \mathrm{N}\left(-\mathrm{d}_{2}\right)-\mathrm{S}_{0} \mathrm{~N}\left(-\mathrm{d}_{1}\right)$

Where:

$$
\begin{aligned}
& \mathrm{d}_{1}=\frac{\operatorname{Ln}\left(\frac{\mathrm{S}_{0}}{\mathrm{X}}\right)+\left(\mathrm{r}+\frac{\sigma^{2}}{2}\right) \mathrm{T}}{\sigma \sqrt{\mathrm{T}}} \\
& \mathrm{d}_{2}=\frac{\operatorname{Ln}\left(\frac{\mathrm{S}_{0}}{\mathrm{x}}\right)+\left(\mathrm{r}+\frac{\sigma^{2}}{2}\right) \mathrm{T}}{\sigma \sqrt{\mathrm{T}}}=\mathrm{d}_{1}-\sigma \sqrt{\mathrm{T}}
\end{aligned}
$$

Where:

C : current call option value

$\mathrm{p} \quad$ :current put option value

$\mathrm{S}_{0} \quad$ :current stock price

$X \quad$ :exercise price

$r \quad$ : risk-free interest rate (the annualized continuously compounded rate on a safe asset with the same maturity as the expiration date of the option, which is to be distinguished from $r \mathrm{f}$, the discrete period interest rate)

$\mathrm{T}$ : time to expiration of option. in years

$\delta \quad$ :standard deviation of the annualized continuously compounded rate of return of the stock

$N(d)$ : the probability that a random draw from a standard normal distribution will be less than $\mathrm{d}$ 
e

:base natural log function, approximately 2.71828

The function $\mathrm{N}(\mathrm{d})$ is the cumulative probability distribution for a standardized normal distribution. In other words, it is the probability that a variable with a standard normal distribution, $\varnothing(0,1)$, will be less than $x$.

\section{Option Straddle Strategy}

According to Hull (2009), a straddle is one which involves buying a call and put with same strike price and expiration date. If the stock price is close to the strike price at expiration of the options, the straddle leads to a loss. However if there is a sufficiently large move in either direction, a significant profit will result. A straddle is appropriate when an investor is expecting a large move in a stock price but does not known in which direction the move will be.

A straddle buyer buys a call and a put option and the seller sells a call and a put option at the exercise price and the same expiration date. The maximum loss associated with the long straddle is the premium paid. Profit potential is unlimited when the prices of the underlying asset rise significantly and limited when it falls significantly.

Tripathy (2011) examined the affect of macroeconomic variable on Indian stock market volatility in the period of January 2005 to January 2011 by using ARCH, GARCH, EGARCH, TARCH, PGARCH, and component ARCH models. Time series weekly data have been collected from www.rbi.com and www.bse.com for a period of 5 years from January 2005 to January 2011 and selected 6 real economic variables as systematically affecting stock returns. The BSE Sensitive Index is used as a proxy for the Indian stock market. Treasury bill rates are taken as proxy for short term interest rate. Similarly WPI is taken as proxy for inflation rate. BSE Sensex is taken proxy for Indian stock market. S\&P 500 has taken as proxy for international market. The research shows that establishes the leverage effect of macroeconomic variable on stock market and suggests that bad news of macro-

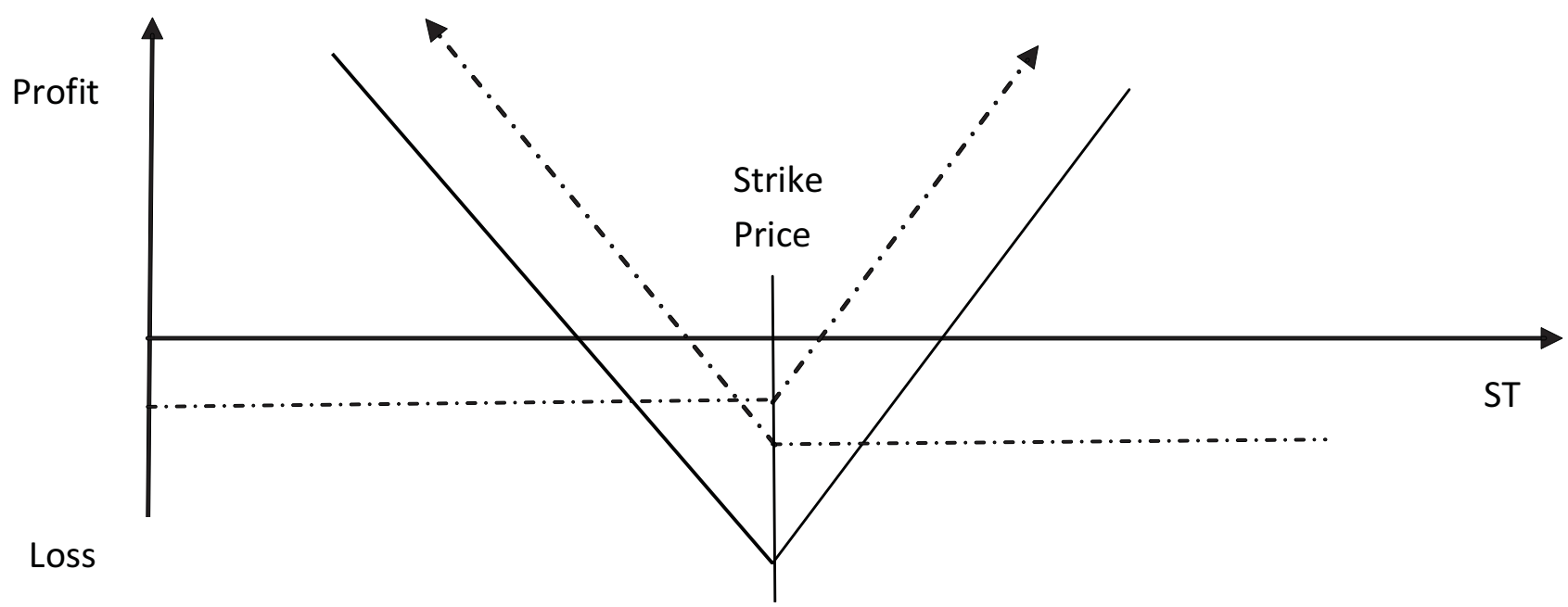

Figure 3. Long Straddle Option Strategy 
economic variable augment the stock market volatility more.

Karbe, Pfaffel, \& Stelzer (2012) investigated stochastic volatility using Black-Scholes model to find the best model. The calibration was performed by choosing the model parameters so as to minimize the root mean squared error (RMSE) between the Black-Scholes volatilities implied by market and model prices. Obtained the option price data from EUWAX on April 29 ${ }^{\text {th }}, 2010$, at the end of the business day. As aproxy for the instantaneous riskless interest rate they took the 3-months LIBOR for each currency. All call options here are plain vanilla call options of european style. They used 148 call options on the EUR/ USD exchange rate, 67 call options on the GBP/ USD exchange rate, and 105 call options on the EUR/ GBP exchange rate. All of them for different strikes and different maturities, for a total of 320 option prices. Findings from their research shows that there is quite some improvement in fitting the margins, but the multivariate options are not fit much better.

He, Lai, \& Xiang (2012) paper proposes a novel multivariate wavelet denoising approach for estimating value at risk for portfolio in the crude oil markets. The data source is the Energy Information Administration Department of Energy US. The date range from January $2^{\text {nd }}, 2002$ to October $1^{\text {st }}, 2009$ for both markets and test the in-sample performance of the models with different specifications with the reserved model tuning set to determine model specification. The size of in-sample model tuning set for the selection of model specification is 387 . Findings from their research shows that in-sample experiment results $p$ value of backtesting procedure is $(0.0805$, 0.0366, and 0.0166) for the EWMA model and $(0.6436,0.4653$, and 0.7501$)$ for the MGARCH model. Using exceedances and their associated Kupiec backtesting statistics as performance measure, they determine the optimal model specification demonstrating the highest level of reliability as indicated by the higher $\mathrm{p}$ value.
Ahmad (2013) investigated GARCH models for inflation volatility in Oman. Monthly data of consumer's price index (CPI) of Oman was obtained from the website of Ministry of National Economy over a period of January 2001 to September 2011 comprising 129 data values. The inflation was measured as 100 times the first differences of the logarithms of the CPI. Based on these criterion, it was observed that e-GARCH specifications clearly performs better than s-GARCH while the ARIFMA model fits better than ARMA in both specifications indicating that long memory models may be best suited for forecasting inflation volatility in Oman as was the case for the US. More over the conditional variance was better represented by e-GARCH rather than s-GARCH model. It was, therefore, suggested that e-GARCH (1.1)-ARFIMA(1.d.1) model with skewed generalized error distribution of residuals should be preferred for short term forecasting.

Sudha (2015) assess the performance of India's sustainability index, the daily data of the ESG India Index are used for the period January $3^{\text {rd }}, 2005$ to September $14^{\text {th }}, 2012$. Two broad market proxies are used in the study are the CNX Nifty index that comprises of 50 representative stocks of the approximately 1,600 listed companies of the NSE and the CNX 500 Index. All the historical price data pertaining to the 3 indices for the aforesaid period have been obtained from the NSE website. The 91-day treasury bill rate published weekly/fortnightly by the Reserve Bank of India is considered as the riskfree interest rate. The results indicate that though the daily compounded returns to the ESG India Index are not statistically different from those of the Nifty or those of the CNX 500. Annualised returns of the ESG India Index have been better than the returns of the other 2 indexes and there is significant volatility clustering in all the 3 indexes. The ESG India Index has been less volatile compared with the Nifty during the period. 


\section{Assessing Shock Volatility using Long Straddle Option Strategy: Evidence at IDX Composite}

Riko Hendrawan

Londoño \& Sandoval (2015) investigated the implied volatility surface from closing mid-prices of plain vanilla calls and puts written over the S\&P 500 every Tuesday from December $5^{\text {th }}, 2007$ until December $3^{\text {rd }}, 2008$. The year 2008 represents a challenge to any model that intends to recover implied volatility from market option prices. They compare Heston model and the linear model. Findings from their research shows that the standard deviation of the linear model error was lower than the one estimated using the Heston model. Moreover, the linear model seemed to adjust better from September $17^{\text {th }}$ to November $5^{\text {th }}$, that was the period with the highest volatility.

Elenjical et al. (2016) conducted a comparative analysis on the performances of $10 \mathrm{GARCH}$ type and 2 less sophisticated statistical type models for estimating $\mathrm{VaR}$ under changing market conditions. Utilised data from the South African market as a representative of the emerging market and is segmented into 3 sub-periods (or regimes) namely the pre 2008 crisis period, the subprime mortgage crisis of 2008, and the post-crisis period. The empirical results contrasted prior research and offered various useful implications. When model performances were evaluated, solely premised on the full range of data spanning across different market conditions or regimes. The long memory GARCH-based models proved to be the preferred choice for $\mathrm{VaR}$ estimation. More importantly, they empirical findings emphasises the potential pitfall when utilising $\mathrm{VaR}$ as a risk management tool to specify the minimum regulatory capital requirement under varying market conditions. Failure to account for such changes in the market condition could lead to severe model misspecifications and incorrect model selections.

Çýnar \& Uzmay (2017) studied to help policy makers in understanding the causes of volatility in food prices and assessing the effectiveness of policies employed. Using monthly data between January 2000 and December 2015 were used. The fear
(VIX) index data is collected from the Chicago Board Options Exchange website. The Food Prices Index (FPI) data is collected from the official website of Food and Agriculture Organization of the United Nations (FAO). According to the findings, 2 important results are stated. Firstly, the financial developments in developed countries, such as the US is influent over food prices. Because of globalization, the global negative developments may affect different markets on a short-term and increase the vulnerability of markets. More importantly, the increasing numbers of import in developing nations made the domestic food prices to be integrated to the international prices. Secondly, it has been found that the volatility effect of food prices increased after the year 2007, compared to the previous period. Based on this information, the food prices had a breakpoint at that period and became more dependent on the present financial indicators. Therefore, the agriculture market may face a pricing factor exceeding the supply and demand equilibrium. This suggests the need for observing financial markets. The participation of financial institutions to the commodity markets should be followed closely. Especially the active commodity trading by big investment banks should be kept under control. Strengthening financial regulations on commodity markets may reduce their effect over food prices.

Patil, Madhuri, \& Jha (2017) investigated the presence of volatility clustering and model the volatility profile over a period of 10 years of Bank Nifty index. The data for this study was collected from www.aceanalyser.com on the daily closing indices of Bank Nifty index for the period starting from April 1 ${ }^{\text {st }}, 2005$ to March 31 $1^{\text {st }}, 2016$. In their study, presence of volatility clustering of Bank Nifty index is tested using ARIMA and ARCH/GARCH models. The daily closing prices of Bank Nifty index for 10 years starting from April 1 ${ }^{\text {st }}, 2005$ to March $31^{\text {st }}, 2016$ was collected and modeled using GARCH model. They study uses extensive post-model diagnostics for acceptance or rejection of the model and 
the results of the study show that the log-returns of Bank Nifty index follow ARIMA (0.0.1) model and the volatility follows GARCH (1.1) model.

Hendrawan (2017) evaluate, analyze, and test derivative instruments (forward and forward option) in the framework of hedging Rupiah currency against USD. Using the time span from 2006-2016 using the exchange rate of Bank Indonesia middle value obtained from the website of Bank Indonesia (www.bi.go.id). Risk-free interest rate (risk free rate) used is BI Rate (the period of 2006 up to July 2016) and BI 7 days report (August 2016 to December 2016), to the interest rate in Indonesia. The use of BI 7 Report days since the period August 2016 to December 2016, because BI rate is not eliminated and replaced with BI 7 days report. As for risk-free interest rate used in the US is treasury bills (T-Bills) with a 3-months period obtained from the website of the Federal Reserve (www.federalreserve.gov). The use of BI and BI 7 days report in Indonesia and treasury bill yields to synchronize the short number of risk-free assets with instruments forward and forward option. For no hedging strategy there are 132 simulations, resulting in total observation of 396 observations. From this study, theoretically proves that the function of derivatives as a hedging tool. In this case is a forward contract provides empirical evidence which shows that 8 out of 11 years of observation shows 72.73 percent benefit (profit), if done in a protected value. Whereas if it is not done hedges, only shows 4 of the 11 years of observation, or about 36.36 percent.

\section{METHODS}

The data in this study used the time frame from January $2^{\text {nd }}, 1998$ to December $30^{\text {th }}, 2016$ for the estimation period and the time frame from January $31^{\text {st }}, 1998$ to January $31^{\text {st }}, 2017$ for model testing. The composite stock price index data from www.duniainvestasi.com used the data feed from IDX, so there are not discrepancies between duniainvestasi and IDX. The secondary data are divided into 2 sections: (1) the estimation data where the IDX Composite has high volatility, ie 1998, 1999, 2004, 2006, 2007, 2008, and 2011. Estimated data in the year that has high volatility for 7 years with a total of 1716 observations. From 1716 observations will be conducted 2 simulation on the call option as many as 1716 and put option 1716 to the total simulation of 3432; and (2) estimated data where IDX Composite has low volatility, ie 2000, 2001, 2002, 2003, 2005, 2009, 2010, 2012, 2013, 2014, 2015, and 2016. Estimated data in a year that has a low volatility for 12 years with a total of 2764 observations. From 2764 observations will be conducted 2 simulation on the call option of 2908 and put option of 2908 to a total of 5528 simulations.

Total estimation data from 1998-2016 with a total of 4480 observations. From 4480 observations will be conducted 2 simulation on the call option of 4480 and put option of 4480 to a total of 8960 simulations. In this period of estimation is determined historically volatility each year. After obtaining its volatility value, the next step is to determine the closing level of early month of IDX Composite. Exercise price, risk free rate, and option period in this research is one month. Finally, calculation of call and put option value is based on analytical model of Black-Scholes model. In this model, volatility shock occurs when the price on the due date is greater than the contract price plus the premium call and put premium for call option, and the price on the due date is greater than the contract price minus the premium call and put premium for option put.

The data used to test the model is the secondary data of the closing stock price index for the period of January $31^{\text {st }}, 1998$ to January $31^{\text {st }}, 2017$. If the due date falls on a holiday, then the execution date uses the price of the working day after the holiday. Testing of research results conducted by Hendrawan (2017): (1) calculating the probability the shock volatilty using long straddle strategy during high volatility and low volatility; and (2) calcu- 
lating the profit or loss of using long straddle strategy during high volatility and low volatility.

\section{RESULTS}

\section{Shock Volatility in High Volatility Years}

Based on the Table 2 shows that during periods of years of high volatility, by observing 3432 call and put transactions, with 1716 call transactions and 1716 put transactions respectively. Indicating that on average there were 34.49 percent shock volatility, where the index rose above the historical average of 22.49 percent and the index fell below the historical volatility of 12 percent. If the shock return occurs then during the period of high volatility then the index jumped by 65.20 percent while the index declined by 34.80 percent.

Especially in the economic crisis year of 1998 and 2008, showed that the jump in index decline is greater than the index spike. In 1998 of 91 volatility shock events showed 58.24 percent of the occurrence of the index decline above the historical volatility and 41.76 percent increase in the index above the historical volatility. Similar results with different percentages were also shown in 2008, where there were 85 volatility shock events showing 76.47 percent of the index decline over historical volatility and 23.53 percent of the increase in the index over historical volatility.

The highest volatility shock occurred in 2006 with 110 events, with an 80 percent volatility shock occurrence of an increase in the index over historical volatility and a 20 percent occurrence of an index decline over historical volatility. While the highest volatility shock occurred in 2011 with 45 events, with 51.11 percent events shock volatility index increase over historical volatility and 48.89 percent occurrence of the index decline over historical volatility.

\section{Shock Volatility in Low Volatility Years}

While based on the Table 3 shows that during periods of years of low volatility, by observing 5528 call and put transactions, with 2764 call transactions and 2764 put transactions respectively. In-

Table 2. Shock Volatility in High Volatility Years

\begin{tabular}{|c|c|c|c|c|c|c|c|c|}
\hline \multirow{2}{*}{$\begin{array}{r}\text { Year } \\
2011\end{array}$} & \multirow{2}{*}{$\begin{array}{c}\text { Simulations } \\
492\end{array}$} & \multicolumn{2}{|c|}{ Position } & \multirow{2}{*}{$\begin{array}{r}\begin{array}{r}\text { Shock } \\
\text { Return }\end{array} \\
23\end{array}$} & \multirow{2}{*}{$\begin{array}{c}\begin{array}{c}\text { Total Shock } \\
\text { Return }\end{array} \\
45\end{array}$} & \multirow{2}{*}{$\begin{array}{c}\begin{array}{c}\% \text { of } \\
\text { Shock Return }\end{array} \\
9.35\end{array}$} & \multicolumn{2}{|c|}{$\begin{array}{c}\text { Total \% of } \\
\text { Shock Return }\end{array}$} \\
\hline & & Call & 246 & & & & Call & 51.11 \\
\hline & & Put & 246 & 22 & & 8.94 & Put & 48.89 \\
\hline \multirow[t]{2}{*}{2008} & 474 & Call & 237 & 20 & 85 & 8.44 & Call & 23.53 \\
\hline & & Put & 237 & 65 & & 27.43 & Put & 76.47 \\
\hline \multirow[t]{2}{*}{2007} & 492 & Call & 246 & 79 & 93 & 32.11 & Call & 84.95 \\
\hline & & Put & 246 & 14 & & 5.69 & Put & 15.05 \\
\hline \multirow[t]{2}{*}{2006} & 490 & Call & 245 & 88 & 110 & 35.92 & Call & 80.00 \\
\hline & & Put & 245 & 22 & & 8.98 & Put & 20.00 \\
\hline \multirow[t]{2}{*}{2004} & 490 & Call & 245 & 65 & 81 & 26.53 & Call & 80.25 \\
\hline & & Put & 245 & 16 & & 6.53 & Put & 19.75 \\
\hline \multirow[t]{2}{*}{1999} & 496 & Call & 248 & 73 & 87 & 29.44 & Call & 83.91 \\
\hline & & Put & 248 & 14 & & 5.65 & Put & 16.09 \\
\hline \multirow[t]{2}{*}{1998} & 498 & Call & 249 & 38 & 91 & 15.26 & Call & 41.76 \\
\hline & & Put & 249 & 53 & & 21.29 & Put & 58.24 \\
\hline \multirow{2}{*}{ Total } & 3432 & Call & 1716 & 386 & 597 & 22.49 & Call & 65.20 \\
\hline & 3432 & Put & 1716 & 206 & 392 & 12.00 & Put & 34.80 \\
\hline \multicolumn{6}{|c|}{ Total Cumulative \% of Shock Return } & & & 34.49 \\
\hline
\end{tabular}


dicating that on average there were 44.25 percent shock volatility, where the index rose above the historical average of 27.28 percent and the index fell below the historical volatility of 16.97 percent. If the shock return occurs then during the period of high volatility then the index jumped by 61.65 percent while the index declined by 38.35 percent.

The highest volatility shock occurred in 2002 with 161 events, with an 47.2 percent volatility shock occurrence of an increase in the index over historical volatility and a 52.8 percent occurrence of an index decline over historical volatility. While the lowest volatility shock occurred in 2012 with 45 events, with 52.94 percent events shock volatility index increase over historical volatility and 47.06 percent occurrence of the index decline over historical volatility.
Interestingly, during the low volatility period of the year there were 3 years of volatility shocks that indicated a downward movement in the indexes of 2000, 2002, and 2015. In 2000 of 107 volatility shock events showed 86.92 percent of the occurrence of the index decline above the historical volatility and 13.08 percent increase in the index above the historical volatility. Similar results with different percentages were also shown in 2002, where there were 161 volatility shock events showing 52.8 percent of the index decline over historical volatility and 47.20 percent of the increase in the index over historical volatility. And also in 2015 of 102 volatility shock events showed 67.65 percent of the occurrence of the index decline above the historical volatility and 32.35 percent increase in the index above the historical volatility.

Table 3. Shock Volatility in Low Volatility Years

\begin{tabular}{|c|c|c|c|c|c|c|c|c|}
\hline \multirow{2}{*}{$\begin{array}{c}\text { Year } \\
2016\end{array}$} & \multirow{2}{*}{$\begin{array}{c}\text { Simulations } \\
490\end{array}$} & \multicolumn{2}{|c|}{ Position } & \multirow{2}{*}{$\begin{array}{r}\begin{array}{c}\text { Shock } \\
\text { Return }\end{array} \\
66\end{array}$} & \multirow{2}{*}{$\begin{array}{c}\begin{array}{c}\text { Total Shock } \\
\text { Return }\end{array} \\
66\end{array}$} & \multirow{2}{*}{$\begin{array}{c}\begin{array}{c}\% \text { of } \\
\text { Shock Return }\end{array} \\
26.94\end{array}$} & \multicolumn{2}{|c|}{$\begin{array}{c}\text { Total \% of } \\
\text { Shock Return }\end{array}$} \\
\hline & & Call & 245 & & & & Call & 100.00 \\
\hline & & Put & 245 & 0 & & 0.00 & Put & 0.00 \\
\hline \multirow[t]{2}{*}{2015} & 488 & Call & 244 & 33 & 102 & 13.52 & Call & 32.35 \\
\hline & & Put & 244 & 69 & & 28.28 & Put & 67.65 \\
\hline \multirow[t]{2}{*}{2014} & 486 & Call & 243 & 37 & 41 & 15.23 & Call & 90.24 \\
\hline & & Put & 243 & 4 & & 1.65 & Put & 9.76 \\
\hline \multirow[t]{2}{*}{2013} & 478 & Call & 239 & 72 & 133 & 30.13 & Call & 54.14 \\
\hline & & Put & 239 & 61 & & 25.52 & Put & 45.86 \\
\hline \multirow[t]{2}{*}{2012} & 488 & Call & 244 & 18 & 34 & 7.38 & Call & 52.94 \\
\hline & & Put & 244 & 16 & & 6.56 & Put & 47.06 \\
\hline \multirow[t]{2}{*}{2010} & 490 & Call & 245 & 84 & 103 & 34.29 & Call & 81.55 \\
\hline & & Put & 245 & 19 & & 7.76 & Put & 18.45 \\
\hline \multirow[t]{2}{*}{2009} & 480 & Call & 240 & 84 & 103 & 35.00 & Call & 81.55 \\
\hline & & Put & 240 & 19 & & 7.92 & Put & 18.45 \\
\hline \multirow[t]{2}{*}{2005} & 486 & Call & 243 & 89 & 131 & 36.63 & Call & 67.94 \\
\hline & & Put & 243 & 42 & & 17.28 & Put & 32.06 \\
\hline \multirow[t]{2}{*}{2003} & 486 & Call & 243 & 114 & 121 & 46.91 & Call & 94.21 \\
\hline & & Put & 243 & 7 & & 2.88 & Put & 5.79 \\
\hline \multirow[t]{2}{*}{2002} & 244 & Call & 122 & 76 & 161 & 62.30 & Call & 47.20 \\
\hline & & Put & 122 & 85 & & 69.67 & Put & 52.80 \\
\hline \multirow[t]{2}{*}{2001} & 434 & Call & 217 & 67 & 121 & 30.88 & Call & 55.37 \\
\hline & & Put & 217 & 54 & & 24.88 & Put & 44.63 \\
\hline \multirow[t]{2}{*}{2000} & 478 & Call & 239 & 14 & 107 & 5.86 & Call & 13.08 \\
\hline & & Put & 239 & 93 & & 38.91 & Put & 86.92 \\
\hline \multirow{2}{*}{ Total } & & Call & 2764 & 754 & & 27.28 & Call & 61.65 \\
\hline & 5528 & Put & 2764 & 469 & 1223 & 16.97 & Put & 38.35 \\
\hline Total Cur & ives $\%$ of Shoc & Return & & & & & & 44.25 \\
\hline
\end{tabular}




\section{DISCUSSION}

From this research theoretically proves that long straddle option strategy can answer the phenomenon of the problem of shock volatility during the year 1998-2016. If detailed during periods of years that have high volatility and especially in times of economic crisis occurs then the possibility of shock volatility towards the decline of the index far greater than. In 1998 volatility shock towards the index decline of 58.24 percent, while in 2008 the shock of volatility towards the index decline of 76.47 percent.

Furthermore, the results of this study indicate that the shock volatility occurs greater when the volatility below the average year of observation. Shock volatility during the year low volatility of 44.25 percent, while shock volatility period of year high volatility of 34.49 percent. But if calculated in total year observation, that is year 1998-2016 show that based on 8960 observation, where 4480 is call option and 4480 transaction is put transaction there is 1815 incident shock volatility or equal to 40.51 percent. This suggests that for an average 1 year period if the transaction year is 250 days, the probability of occurring volatility shock of 101 days. Be it an increase in the index price above the historical volatility or the decline of the index below the historical volatility.

The results of this study further sharpen the research conducted by Tripathy (2011), Karbe, Pfaffel, \& Stelzer (2012), Sudha (2015), Çýnar \& Uzmay (2017), Patil, Madhuri, \& Jha (2017), where this research is able to explain the possibility of shock volatility that will affect the decrease or increase of investment instruments abnormally.

Practical implications, from the results of this study is not always shock volatility bring a negative impact. The choice of instruments and investment strategies also become very important for investors. The results of this study indicate that in total during 1998-2016 showed that despite the shock volatility, with the strategy of long straddle option strategy, investors still have a chance of profit gain of 40.51 percent. The opportunity to gain profit will be even greater when the occurrence of a volatility surge over its history, in this case when the economic crisis occurs. Indicates that the probability of profits exceeds 50 percent, as occurred in 1998 of 58.24 percent and the year 2008 amounted to 76.47 percent. But further results obtained from this study are the findings that despite low volatility shocks on average, in 2000, 2002, and 2015. The result indicates that indicates that the probability of profits exceeds 50 percent, as occurred in 2000 of 86.92 percent, in 2002 of 52.8 percent, and in 2015 of 67.65 percent. This means investors benefit by using option straddle strategy even if the condition of using IDX Composite decreases.

\section{CONCLUSION AND SUGGESTIONS}

\section{Conclusion}

This study has a goal to identify the probability of occurrence of shock volatility and its impact on return of an investment. Using IDX Composite data from 1998-2016 using long straddle option strategy at idx composite consisting of 2 phases: (1) high volatility daily return of IDX Composite in 1998, 1999, 2004, 2006, 2007, 2008, and 2011; and (2) low volatility daily return of IDX Composite in 2000, 2001, 2002, 2003, 2005, 2009, 2010, 2012, 2013, 2014, and 2015. Estimated data in the year that has high volatility for 7 years with a total of 1716 observations. From 1716 observations will be conducted 2 simulations on the call option as many as 1716 and put option 1716 to the total simulation of 3431 .

Estimated data in a year that has a low volatility for 12 years with a total of 2764 observations. From 2764 observations will be conducted 2 simulations on the call option of 2908 and put option of 2908 to a total of 5528 simulations. Total estimation data from 1998-2016 with a total of 4480 observations. From 4480 observations will be conducted 2 
simulations on the call option of 4480 and put option of 4480 to a total of 8960 simulations. The data used to test the model is the secondary data of the closing stock price index for the period of January $31^{\text {st }}, 1998$ to January 31 ${ }^{\text {st }}, 2017$.

The result shows that the results of this study indicate that the shock volatility occurs greater when the volatility below the average year of observation. Shock volatility during the year low volatility of 44.25 percent, while shock volatility period of year high volatility of 34.49 percent. But if calculated in total year observation, that is year 1998-2016 show that based on 8960 observation. Where 4480 is call option and 4480 transaction is put transaction there is 1815 incident shock volatility or equal to 40.51 percent. The results of this study further sharpen the research conducted by Tripathy (2011), Karbe, Pfaffel, \& Stelzer (2012), Sudha (2015), Çýnar \& Uzmay (2017), Patil, Madhuri, \& Jha (2017). Where this research is able to explain the possibility of shock volatility that will affect the decrease or increase of investment instruments abnormally.

Practical implications, from the results of this study is not always shock volatility bring a nega- tive impact. The choice of instruments and investment strategies also become very important for investors. The results of this study indicate that in total during 1998-2016 showed that despite the shock volatility, with the strategy of long straddle option strategy, investors still have a chance of profit gain of 40.51 percent. The opportunity to gain profit will be even greater when the occurrence of a volatility surge over its history. In this case when the economic crisis occurs, indicates that the probability of profits exceeds 50 percent, as occurred in 1998 of 58.24 percent and the year 2008 amounted to 76.47 percent.

\section{Suggestions}

The implications of this research theoretically and practically proves that the choice of hedging instruments to cope with volatility is very important. But this research also shows that not only the hedging instrument but also the strategy chosen to anticipate the volatility shock becomes very important. For further research it can be used in other instruments such as currency, stock or others, and can be fired by using stochastic volatility.

\section{REFERENCES}

Ahmad, M. I. (2013). GARCH models for inflation volatility in Oman. Review of Integrative Business and Economics Research, 2(2), 1-7.

Bodie, Z., Kane, A., \& Marcus, A. J. (2014). Investments. 10 ${ }^{\text {th }}$ Edition. New York: Mc.Graw Hill.

Çýnar, G., \& Uzmay, A. (2017). Does fear (vix index) incite volatility in food prices? International Journal of Food and Agricultural Economics, 5(2), 69-78.
Elenjical, T., Mwangi, P., Panulo, B., \& Huang, C. (2016). A comparative cross-regime analysison the performance of GARCH-based value-at-risk models: Evidence from the Johannesburg Stock Exchange. Risk Management, 18(2-3), 89-110.

He, K., Lai, K. K., \& Xiang, G. (2012). Portfolio value at risk estimate for crude oil markets: A multivariate wavelet denoising approach. Energies, 5(4), 10181043.
Hendrawan, R. (2017). Forward, forward option, and no hedging which one is the best for managing currency risk? Jurnal Keuangan dan Perbankan, 21(3), 356-365.

Hull, J. C. (2009). Options, futures, and other derivatives. 7th Edition. New Jersey: Prentice Hall.

Karbe, J. M., Pfaffel, O., \& Stelzer, R. (2012). Option pricing in multivariate stochastic volatility models of OU type. SIAM Journal of Financial Math, 3(1), 66-94. 
Londoño, J. A., \& Sandoval, J. (2015). A new logistic type-model for pricing European options. SpringerPlus, 4, 762.

Patil, A., Madhuri, G., \& Jha, B. (2017). Modeling volatility clustering of bank index: An empirical study of Bank Nifty. Review of Integratif Business and Economics Research, 6(1), 224-239.

Sudha, S. (2015). Risk-return and volatility analysis of sustainability index in India. Environmental, Development, and Sustainability: A Multidisciplinary Approach to the Theory and Practice of Sustainable Development, 17(6), 13291342.

Tripathy, N. (2011). Forecasting volatility of Indian stock market and macroeconomic variables. International Journal of Arts $\mathcal{E}$ Sciences, 4(9), 225-238. 